\title{
WOMEN'S HEALTH AND THE PHENOMENON OF DRUGS IN BRAZILIAN MAGAZINES ${ }^{1}$
}

\author{
Márcia Rebeca Rocha de Souza², Jeane Freitas de Oliveira3 , Enilda Rosendo do Nascimento ${ }^{4}$
}

\begin{abstract}
${ }^{1}$ An article elaborated from the study entitled - O fenômeno das drogas e a saúde das mulheres na mídia escrita brasileira: uma análise de gênero, approved by the Institutional Program for Scientific Initiation Scholarships (PIBIC), for the period 2009/2010, with funding from the Bahia Research and Extension Foundation (FAPESB).

${ }^{2}$ Master's students at the Graduate Program in Nursing, School of Nursing, Federal University of Bahia (UFBA). Salvador, Bahia, Brazil. E-mail: marciabek@hotmail.com

${ }^{3}$ Ph.D. in Collective Health. Professor at the School of Nursing, UFRGS. Bahia, Brazil. E-mail: jeanefreitas@ig.com.br

${ }^{4}$ Ph.D. in Nursing. Professor at the School of Nursing, UFRGS. Bahia, Brazil. E-mail: enildarosendo@hotmail.com
\end{abstract}

ABSTRACT: The aim of this paper is to discuss social and health repercussions in women due to drug use, as disclosed in reports published in magazines with national circulation. This is a qualitative research, with an exploratory and descriptive approach. Articles published in four magazines were used, during six consecutive months as of September of 2009. Fifty-two articles were identified with comments on women and the drug phenomena. The information was addressed by means of thematic content analysis. The reports address the increased consumption of drugs by women, the consumption of drugs to maintain and/or achieve the established sociocultural standards of beauty, with risks for addiction and overdose, and situations resulting from violence towards women living with male drug users. Economical, political, ideological and cultural reflexes for women involved with the drug phenomena could be the cause or consequence of implications in the health of this population.

DESCRIPTORS: Women. Drug users. Mass media.

\section{A SAÚDE DE MULHERES E O FENÔMENO DAS DROGAS EM REVISTAS BRASILEIRAS}

RESUMO: Este artigo tem como objetivo discutir as repercussões sociais e na saúde de mulheres envolvidas com drogas, divulgadas em reportagens publicadas em revistas de circulação nacional. Trata-se de uma pesquisa qualitativa, de caráter exploratório e descritivo. Utilizou-se reportagens publicadas em quatro revistas, durante o período de seis meses consecutivos, a partir de setembro de 2009. Foram identificadas 52 reportagens que comentavam sobre as mulheres e o fenômeno das drogas. Para o tratamento dos dados, adotou-se a análise de conteúdo temática. As reportagens abordam aumento do consumo de drogas por mulheres, o consumo de medicamentos para manter e/ou atingir padrões de beleza socioculturalmente estabelecidos, com riscos para dependência e overdose, e situações de violências para mulheres decorrentes da convivência com homens usuários de drogas. Os reflexos econômicos, políticos, ideológicos e culturais para mulheres envolvidas com o fenômeno das drogas podem ser causa e/ou consequência das implicações para a saúde desta população.

DESCRITORES: Mulheres. Usuários de drogas. Meios de comunicação de massa.

\section{LA SALUD DE LAS MUJERES Y EL FENÓMENO DE LAS DROGAS EN REVISTAS BRASILEÑAS}

RESUMEN: Este artículo tiene como objetivo discutir las repercusiones sociales y en la salud de las mujeres involucradas con drogas, divulgadas en reportajes publicadas en revistas de circulación nacional. Se trata de una pesquisa cualitativa, de carácter exploratorio y descriptivo. Se utilizó reportajes publicados en cuatro revistas, durante el periodo de seis meses consecutivos, a partir de septiembre del 2009. Fueron identificados 52 reportajes que comentaban sobre las mujeres y el fenómeno de las drogas. Para el tratamiento do los datos, se adoptó el análisis de contenido temático. Los informes apuntan el aumento del consumo de drogas por las mujeres, el consumo de drogas para mantener y/o alcanzar estándares socioculturales de belleza, con riesgos de adicción y sobredosis y las situaciones derivadas de la violencia de mujeres que viven con hombres usuarios de drogas. Los reflejos económicos, políticos, ideológicos y culturales para las mujeres involucradas con el fenómeno de las drogas pueden ser causa o consecuencia de las implicaciones para la salud de esta población.

DESCRIPTORES: Mujeres. Consumidores de drogas. Medios de comunicación de masa. 


\section{INTRODUCTION}

The production, trade and consumption of drugs constitute a worldwide social and health problem that affects all societies in different ways and involves people of all races, genders, religions, social classes and educational levels.

Social and health repercussion are understood as the economic, political and ideological reflections of women's involvement with drugs, as well as the tendencies of vulnerability to disease and injuries, in face of this issue. Such issues are still not broadly discussed in the Brazilian literature, but they are often reported in mass media communication.

Although involvement with drugs is socially regarded as a male conduct, epidemiological studies (national and international ${ }^{1-2}$ point to an increase in the number of women consuming licit and illicit psychoactive substances, especially medications. With regard to drug trading, data from the National Penitentiary Department (DEPEN) show a marked growth in the incarceration rate of women due to crimes associated with trafficking. ${ }^{3}$

Studies that focus on women, and the issue of illicit drugs, refer to their participation as supporting the process, noting that the involvement occurs through relationships of affection with men in their social environment, as a companion, sibling or neighbor, ${ }^{4-5}$ with few situations in which they appear alone being exploited, as a result of personal choices.

Changes in the late twentieth century are related to post-modernity, causing changes in the lifestyle of all people in different societies, standards of conduct and leisure, including changes in the consumption, production and trade of psychoactive substances. For women specifically, the changes caused, among other aspects, greater integration into the labor market and an increase in the number of families headed by women. ${ }^{6-7}$ The incorporation of women, as kids, teenagers and adults in the social sphere also implies being submitted to the same risk factors to which men are subjected, incorporating habits like drug use.

The historically constructed image of women is not consistent with the image of a drug user and/or participant in the drug trade, contributing to the process of the invisibility of women in the drug phenomenon and consequently a greater vulnerability to social and health problems for this population group. ${ }^{8}$ Physiological aspects that de- termine a differential metabolism of psychoactive substances, making women more sensitive to their effects, also constitute factors of vulnerability. ${ }^{6,9-10}$

Mass media communication, as wideranging and powerful social equipment works in disseminating dominant schemes of meaning and interpretation of the world, influencing the ways of living and thinking of individuals in different social contexts. ${ }^{11}$ Therefore, it is pertinent to consider that mass media contributes to the expansion of the drug phenomenon, along with the processes of urbanization and globalization, ${ }^{12}$ which determine changes in the social, cultural, political and economic contexts of societies. ${ }^{13}$

The creation of effective mechanisms for coping with the expansion of the drug phenomenon is included in the political agenda of many countries. Among the strategies discussed, there is the training of professionals from various fields, including health, so as to be capable of dealing with the multifaceted situations that permeate this phenomenon. ${ }^{14}$

In the scope of health, and specifically women's health, tackling the drug phenomenon goes beyond biomedical dimensions, requiring that professionals understand the health-disease process more broadly, covering the specifics of women as a social subject. Therefore, it is important to understand the inclusion of women in contemporary society, in the social relations they establish and gender inequalities that permeate these relationships. The aim of this paper is to discuss the social and health repercussions in women due to drug use, as disclosed in magazines with national circulation.

\section{METHODOLOGY}

This is an exploratory-descriptive study with a qualitative approach, based from articles published in four Brazilian magazines. Two of the magazines chosen (Veja and Isto É) are published on a weekly basis and discuss various topics ranging from politics, economics, work and health, targeting the general public. The other two (Cláudia and Boa Forma) have monthly editions and their content covers topics related to health, beauty, disease prevention, lifestyle, relationships, fashion, kids and family, targeting women more specifically.

These magazines were chosen based on the following aspects: national circulation with a 
broad range, proven by the number of copies sold at each edition, as per the websites of the publishers themselves, ease of access (print and on-line) and diversity of contents covered for different populations.

For six consecutive months, as of September of 2009, all copies of the magazines (77) were read thoroughly, searching for reports on the problem studied. Initially, the reports were cataloged by title, magazine name, year of publication and edition, and synthesis of the content covered. In this process, 87 stories on the topic of drugs were identified and recorded. Subsequent readings of all the content from these reports allowed the selection of 52, which focused on issues related to drugs and women.

Following the steps for the analysis of thematic content, ${ }^{15}$ it was possible to select those that focused on drug-related issues and women, more specifically about forms of consumption, types of drugs used, reasons for consumption, drugs effects on the body, women's participation in drug trafficking, drug violence and imprisonment for drug trafficking.

The reports were then grouped by similarity of information, which allowed the organization of two thematic categories: 1 ) Drugs that treat and drugs that cause dependence; and 2 ) Female protagonists in the drug phenomenon. The first category contains reports on the use of licit drugs, including medications, tobacco and alcohol, and the second category discusses the use of illicit drugs, women's participation in drug trafficking and violent situations experienced by women as a result of living with people who are drug users.

This is an original article, which did not need to be submitted to a Research Ethics Committee, as its research did not involve human beings directly. Nevertheless, the researchers complied with all ethical principles, as per Resolution 196/96 of the National Health Council.

\section{RESULTS AND DISCUSSION}

The quantity of reports that addressed women's issues and the drug phenomenon (52) represented approximately $60 \%$ of all reports identified, noting that the issue studied is relevant and of interest to the media.

In each thematic category subcategories were identified, revealing the complexity of the subject and the specifics related to women.

\section{Drugs that treat and drugs that cause dependence}

The reports assembled in this category brought guidance and warnings about the use of medications and the onset of signs and symptoms of diseases caused by the consumption of licit psychoactive substances, among them alcohol and tobacco.

In general, the content of the reports had an informative nature, warning about the risk of drug overdose, alcoholism and smoking, such as primary health repercussions associated with the consumption of licit drugs. Secondary to them, the texts mentioned the risks of physical and psychological dependence, anxiety disorders, overweight, respiratory diseases and even death. Related to the repercussions on women's health, the texts highlighted the interference with work and family as social repercussions.

The death of actress Brittany Murphy, which occurred on December 20, 2009, was covered by journalistic articles to discuss the use of medications by women, the risks of addiction and death by usage thereof. The reports used the image of this famous public figure, known worldwide, who was an actress, to show that addiction to drugs reflected negatively on working activities, resulting in difficulties with performance, problems in interpersonal relationships and unemployment, as this excerpt from an article published shows. "[...] a stunning combination of prescription drugs found in Brittany's room would confirm this assumption (a drug overdose). The list includes the analgesic Vicoprofen [...] which causes dependence and may lead to cardiac arrest (cause of death of the actress) as it decreases the respiratory frequency of the user. In addition, the police found bottles of anxiolytics in her room [...]. Brittany's career, relatively strong within the limits of the second tier of Hollywood, was suffering setbacks. Two weeks before her death, she was fired from the production of the film "The Caller" due to her aggressive behavior on the set $[\ldots . .]^{\prime \prime} .{ }^{16: 52}$

The consumption of drugs, particularly stimulants, painkillers and benzodiazepines, is prevalent among women. ${ }^{1-2}$ In Brazil, the percentage of women using benzodiazepines and amphetamines is about three times higher than among men, ${ }^{1,17}$ with their use being carried out in an attempt to solve health problems/illnesses that affect the women's body, and to meet preestablished beauty standards. ${ }^{18}$ 
According to a study conducted on advertisements for antidepressant and anxiolytic medications, ${ }^{19}$ the female figure appears four times more than the male figure, associated with leisure time, rest at home and/or contact with nature. The images transmitted by the advertisements promote the process of medicalization for any uncomfortable situations in everyday life, without any objective indications.

Medical prescription ensures the acquisition of licit chemical substances, which feeds a social tendency to naturally accept the use of medicines by not considering them as drugs. ${ }^{20}$ In addition to the use of prescription drugs by authorized professionals, the cultural phenomenon of overvaluating the consumption of these drugs is considered, stimulated by a reductionist view of the health-disease process. Medicines have acquired the central role of immediate solvers to health problems, also encouraging the perception that every disease requires pharmacological treatment. Medicinal substances then become understood as central instruments in health practices, which influences the exercise of self-medication. ${ }^{21}$

Some reports warn of the risks associated with the practice of medicalization, albeit indirectly, by stimulating the consumption of drugs to cure and/or control diseases through information that had highlighted the benefits of the medications. Another report, based on a social fact the punishment of the Brazilian gymnast Daiane dos Santos, faced with positive results of doping tests conducted in July of 2009, emphasized the adverse effects of drugs on the body and the risks of self-medication. In the field of sports, the use of a socially legal substance, marketed as a medicine, is regarded as an illegal conduct, passive of punishment.

One must consider that the disclosure of information, about medicines and therapeutic treatments, helps to increase the rationality of using them..$^{22}$ In contrast, the accumulation of knowledge and the provision of information shared among peers, neighbors and through communication media help people choose medicines, making them more confident in self-medication.

The messages relayed by the media can be assimilated and interpreted by the public with many meanings. Therefore, it is important to rethink the quality of the information that is disclosed by the media about medicines, since they are an elementary public awareness tool, encouraging advances in the health education process. ${ }^{22}$
Diseases resulting from the abuse of licit drugs, as well as scientific advances in the pharmacological treatment of pathologies, such as obesity, cancer and depression, have been addressed in several reports. Among the diseases arising from illicit drug use were: female alcoholism, as a primary pathology associated with alcohol abuse by women and alcohol anorexia or drunkorexia, characterized as an eating disorder associated with chemical dependence, which leads women to ingest alcoholic beverages to suppress the appetite and therefore lose weight. ${ }^{24}$

Considered as a serious public health problem, alcoholism is one of the most prevalent mental disorders in the Brazilian society, associated with high clinical, social, economic, labor and family losses. In addition, it is also related to different situations of violence, traffic accidents and traumas. ${ }^{25}$

According to one of the reports, "the effects of alcohol are more devastating for women than for men. Diseases arising from alcoholism kill proportionately twice as many female than male alcoholics. Among women, the damage to health caused by addiction to the drink usually appear ten years earlier than among men". 26:86 The health consequences for women who abuse alcohol, identified in the reports, are cardiovascular and neurological disorders, liver disease, cancer, osteoporosis and psychiatric disorders.

Scientific studies show that metabolic and physiological differences between the sexes determine increased sensitivity of women to the effects of alcohol and therefore greater vulnerability to alcohol dependence syndrome and to the physiological damages related to it. Women start the consumption of alcoholic beverages later in relation to men, however, they present the resulting pathologies of this consumption earlier. ${ }^{9-10,27}$

Although reports indicate the consequent health repercussions from alcohol abuse, the emphasis on social and psychological aspects, such as loss of self-esteem, difficulties in interpersonal relationships, impaired work performance and commitment to family stability, point to aspects of gender differences.

An excerpt from one of the early reports denouncing the consumption of alcoholic beverages during the teenage years, related to an unspecified eating disorder: "in my teenage years, I did every kind of diet, but, as I loved to drink, I did not cut out alcohol at all. I used menus in which $80 \%$ of the 
calories came from the drink, as I believed that this way I would not get fat (...). Until one day I had a panic attack, I thought I was going to die (...). At the hospital, they became suspicious of an eating disorder, because I had liver problems and I was almost malnourished (...)". 24:109

The association between the use of psychoactive substances by women and weight reduction has already been discussed in national literature. ${ }^{28-29}$ Nevertheless, it is noteworthy that there are difficulties in getting population samples to conduct more specific research on this topic due to the common association between eating disorders, drug dependence and other psychiatric disorders, such as mood and anxiety disorders. ${ }^{30}$

Whereas the causes and consequences of female alcoholism are more often associated with psychological issues, thus intrinsic to women, in the case of men they relate to social issues. The marks of the genre in alcoholism relate to, among other aspects, the allocation of the phenomenon in the moral dimension, when referred to women. ${ }^{31}$

In this case, moral judgment indicates the failure of women in the fulfillment of the gender roles assigned to them socially and the rejection of behaviors that are not expected from them as a result of loss of control over themselves.

New standards of physical appearance and lifestyles are promoted by mass media, linked to the overriding idea of beauty and a dominated body, domesticated to conquer aesthetic perfection, and with it, happiness. ${ }^{32}$ In this context, some reports have focused on the incompatibility of the habit of smoking with female beauty.

Early last century smoking was seen as a charming accessory imposing power and valuing feminine sensuality. This representation has been transformed over the years and has not constituted itself, today, as a central idea in regard to the use of this drug. ${ }^{33}$ Smoking is considered one of the most important public health problems, being the leading preventable cause of death by nontransmissible chronic diseases. ${ }^{34}{ }^{35}$ Nevertheless, cigarette consumption is growing worldwide, particularly in developing countries. ${ }^{34}$ In Brazil, consumption rates have risen, particularly among young women ${ }^{36}$ and those that have a less favored socioeconomic status. ${ }^{37}$

Exhibiting luminous skin, white teeth, pleasant breath, more opportunities to get a partner and the possibility to increase the chances of pregnancy were highlighted as advantages for the non-use of tobacco by women. The suppression of smoking to prevent non-transmissible chronic diseases such as cancer, and coronary, pulmonary and cerebrovascular diseases, responsible for higher rates of morbidity and mortality related to smoking, were not discussed.

In general, the content of the reports is used in a discursive network through testimonials from renowned professionals and readers who adopted conveyed practices and had satisfactory results, and also data from national and international scientific research to reproduce values that constrain women to practices and behaviors to achieve the ideal beauty and body.

\section{Female protagonist in the drug phenomenon}

The articles assembled in this category essentially deal with two aspects. One of them, still poorly explored in the drug phenomenon, concerns the participation of women in the consumption and trafficking of illicit drugs, not directly related to the influence of sexual partners or friends. In this case, the drugs highlighted in the reports were LSD, ecstasy, alcohol and cocaine.

The second aspect addressed concerns the victimization of women who suffered physical violence from friends or fellow drug users. In the reports, crack and alcohol were mentioned as causes of violence committed against women.

The use of illicit drugs by the female population is a reality still poorly discussed in the national literature, although epidemiological studies confirm the growth of this fact ${ }^{1}$ and the number of female prisoners in the prison system, whose main motive is drug trafficking., ${ }^{3,38}$ Some of these studies point to this fact as a result of unequal gender relations, characterized, among other things, by the submission of women to men. ${ }^{8,39-40}$ Nevertheless, the idea of one's own initiative, a feminine aspect of intentionality as a motivator for consumption and/or trafficking drugs, begins to be considered. ${ }^{4-5}$

Although there was no focus on drug use by the female population, some of the reports dealt with the consumption of synthetic drugs mixed with other substances like medicines, alcohol and cocaine by middle and upper class youths. The images used in the reports showed women dancing at parties, denoting them being under the influence of psychoactive substances, with testimonials of experiences lived by them in the abuse of different psychoactive substances. 
The images and testimonials focused on young women of high social class, attending nightclubs and raves, and who made use of these drugs 'to get as crazy as possible' and enjoy the party. The context of use and the profile of the consumer of synthetic drugs indicated in the reports are compatible with the characteristics already described in a national scientific study. ${ }^{41}$

The consumption of cocaine and crack was approached by the female population in the reports, showing the expansion in the consumption of these psychoactive substances among women of all social classes, races and educational levels. One report told the story of the use of cocaine and crack by a young white woman, belonging to a family of high social class, started at the age of 11, reproducing the abusive use of alcohol and cocaine carried out by her mother, within the house. Although discreetly, the report shows that the problematic use of alcohol and other drugs by women is not a recent problem, as it crosses generations. The type of substance produced and marketed is what changed.

In general, the contents of the articles point to physical and social implications for women, arising from the consumption of illicit drugs, such as: overdose, miscarriages, cardiac and neurological disorders, as well as exposure to violence, family and emotional imbalance, difficulties with insertion and maintenance in the labor market and several hospital admissions for drug dependence treatment.

Regarding the exposure of women in situations of violence committed by their partners or friends who use drugs, the texts found in magazines propagate the idea that the drug acts on individuals, determining their actions, as it was found in a study conducted on newspapers in Salvador, Bahia. ${ }^{42}$ The practice of aggressions and crimes is justified by the effect of illicit drugs to which the aggressor, represented by a male person, is submitted. The report entitled "A brutal drug" confirms this statement in the following excerpt: "under the influence of crack, he strangled student Bárbara Calazans, 18, whom he called 'my guardian angel'". 43:66

The subject of this report was addressed in two of the magazines selected, with similar content. The texts focused on the expansion of crack use among the middle class and considered this increase as a devastating urban epidemic, leading to the classification of crack as a social and health problem. When using expressions like 'crack is essentially a dangerous drug', 'crack brutalizes', and 'crack endangers those who become addicted and often those around you', the media reinforces the idea that the drug is the main element in the addiction process, which acts on the person taking them to act violently and uncontrollably. In this perspective, the drug becomes responsible for acts of crime, violence and aggression committed by people who use it.

In one of the reports, women appeared as victims of physical violence by their partner, a user of alcoholic beverages. The reports published were associated with acts of violence carried out by the football player, Adriano, against his companion, revealing his problematic alcohol consumption.

The relationship of the drug phenomenon with the phenomenon of violence is a consensus in the specialized literature ${ }^{44}$ in which women take the place of victims of physical and/or psychological violence from their companion, who use alcohol and other drugs. The media reproduces the image of docile, naive and caregiving women as the main victim of rampant drug violence, personified in the male user.

\section{FINAL CONSIDERATIONS}

The collection analyzed allows the approach to the problematic drug problem in the female population to be considered meaningful, in the communication media investigated. Among the topics covered in the reports, the risks of medicine consumption were highlighted, as well as the expansion of female alcoholism and smoking, the involvement of women from different social classes, ages and races with drug trafficking and consumption of illicit drugs and, moreover, situations of violence against women resulting from living with drug users.

In the topics addressed, biological repercussions were focused, due to the effects of drugs on the body and the action of these on social and emotional relationships. The submission of women to men, disadvantages related to muscular and physical strength, violent situations, feelings of suffering, the need to meet socially imposed standards of beauty and the family context of substance use were assigned as causes and consequences for women's involvement with drugs. The reproduction of such ideas evidences the association of social and cultural constructs that 
determine health inequalities between people of the same sex and different sexes that are reflected in everyday actions and, consequently, in the consumption of psychoactive substances.

Based on the punishment of an athlete for doping, it was possible to problematize the concept of what is considered licit or illicit in the drug world. The use of diuretics, medications easily accessible in pharmacies, is forbidden in the context of sporting competitions, leading to the punishment of athletes that supposedly make use of them.

Finally, the data analyzed show that the social impacts in the reports studied somehow supplanted health issues, especially affectiveemotional and family imbalance. The content of the reports indicates the reproduction of unequal gender relations in the drug phenomenon, by attributing women's involvement to moral/emotional issues, relegating health and the preservation of life to second place. The data presented indicate the need for planning and redirecting health actions for women, seeking to contemplate the various consequences arising from their involvement with drugs.

\section{REFERENCES}

1. Carlini EA, Galduróz JC, Noto AR, Carlini CM, Oliveira LG, Nappo AS, et al. II levantamento domiciliar sobre o uso de drogas psicotrópicas no Brasil: estudo envolvendo as 108 maiores cidades do país - 2005. São Paulo (SP): Páginas \& Letras; 2007.

2. United Nations Publication. World drug report [online]. 2007 [acesso 2007 Jul 27]. Disponível em: http://www.unodc.org/pdf/research/wdr07/ WDR_2007.pdf

3. Ministério da Justiça (BR). Relatório de Gestão do Departamento Penitenciário Nacional. Brasília (DF): MJ; 2009.

4. Barcinski M. Protagonismo e vitimização na trajetória de mulheres envolvidas na rede do tráfico de drogas no Rio de Janeiro. Ciênc Saúde Coletiva [online]. 2009 [acesso 2010 Jun 21]; 14(2):577-86. Disponível em: http:/ / www.scielosp.org/pdf/csc/ v14n2/a26v14n2.pdf

5. Souza KOJ. A pouca visibilidade da mulher brasileira no tráfico de drogas. Estud Psicol [online]. 2009 [acesso 2011 Nov 22]; 14(4):649-57. Disponível em: http://www.scielo.br/pdf/pe/ v14n4/v14n4a05.pdf

6. Zilberman M. Uso de drogas entre mulheres. In: Baptista M, Cruz MS, Matias R, organizadores. Drogas e pós-modernidade: prazer, sofrimento e tabu. Rio de Janeiro (RJ): EDUERJ; 2003. p.175-85.
7. Romo N. Gênero y uso de drogas: la invisibilidad de las mujeres [online]. 2006 [acesso 2007 Mar 29]; Disponível em: http:/ / www.fundacionmhm.org/ pdf/Mono5/Articulos/articulo4.pdf

8. Oliveira JF. (In)visibilidade do consumo de drogas como problema de saúde pública num contexto assistencial: uma abordagem de gênero [tese]. Salvador (BA): Universidade Federal da Bahia, Instituto de Saúde Coletiva; 2008.

9. Hochgraf PB, Brasiliano S. Mulheres e substâncias psicoativas. In: Seibel SD, organizador. Dependência de drogas. 2a ed. São Paulo (SP): Atheneu; 2010. p.1025-41.

10. Wolle CC, Zilberman ML. Mulheres. In: Laranjeira R, Diehl AC, Cruz D. Dependência química: prevenção, tratamento e políticas públicas. Porto Alegre (RS): Artmed; 2011. p. 375-82.

11. Alexandre M. O papel da mídia na difusão das representações sociais. Comum. 2001 Jul-Dez; 17(6):111-25.

12. Pavarino RN. Teoria das Representações Sociais: pertinência para as pesquisas em comunicação de massa. In: Anais do $26^{\circ}$ Congresso Anual em Ciências da Comunicação [CD-ROM], 2003 Set 0206; Belo Horizonte, Brasil. São Paulo (SP): Intercom; 2003.

13. Wright MGM, Chisman AMG. A saúde internacional, o fenômeno das drogas e a profissão de enfermagem na América Latina. Texto Contexto Enferm [online]. 2004 Jan-Mar [acesso 2010 Abr 07]; 2(1):123-34. Disponível em: http:/ /www.redalyc.org/articulo. oa?id=71413210

14. Wright MGM, Gliksman L, Khenti A. A pesquisa sobre o fenômeno das drogas na perspectiva dos estudos multicêntricos na América Latina e Caribe. Rev Latino-Am Enferm [online]. 2009 Nov-Dez [acesso 2010 Abr 05]; 17(Esp):751-3. Disponível em: http://www.scielo.br/pdf/rlae/v17nspe/en_01. pdf

15. Bardin L. Análise de conteúdo. Lisboa (PT): Edições $70 ; 2007$.

16. Uma tragédia que se repete. Revista Veja, edição 2145, 2009 Dez 30; A semana - Sociedade, 52.

17. Carlini EA, Galduróz JCF, Noto AR, Nappo AS. $1^{\circ}$ levantamento domiciliar sobre o uso de drogas psicotrópicas no Brasil - 2001. São Paulo (SP): CEBRID; 2002.

18. Avilés, NR. Mujeres y drogas de sínteses: gênero y riesgo em la cultura del baile. $3^{\mathrm{a}}$ ed. Donosita (ES): Gakoa; 2001.

19. Mastroianni PC, Vaz ACR, Noto AR, Galduróz JCF. Análise do conteúdo de propagandas de medicamentos psicoativos. Rev Saúde Pública. 2008; 42(5):968-71.

20. Martins ERC, Zeitoune RCG, Francisco MTR. Concepções do trabalhador de enfermagem sobre 
drogas: a visibilidade dos riscos. Rev Enferm UERJ [online]. 2009 Jul-Set [acesso 2010 Jun 06]; 17(3):36872. Disponível em http://www.facenf.uerj.br/ v17n3/v17n3a12.pdf

21. Naves JOS, Castro LLC, Carvalho CMS. Automedicação: uma abordagem qualitativa de suas motivações. Ciênc Saúde Coletiva [online]. 2010 Jun [acesso 2011 Nov 30]; 15(Supl.1):1751-62. Disponível em: http://www.scielo.br/pdf/csc/v15s1/087.pdf

22. Lage EA, Freitas MIF, Acurcio FA. Informações sobre medicamentos na imprensa: uma contribuição para o uso racional? Ciênc Saúde Coletiva [online]. 2005 Set-Dez [acesso 2011 Nov 30]; 10(Supl):1339. Disponível em: http://redalyc.uaemex.mx/ pdf/630/63009916.pdf

23. Silva IM, Catrib AMF, Matos VC. Automedicação na adolescência: um desafio para a educação em saúde. Ciênc Saúde Coletiva [online]. 2011[acesso 2011 Nov 30]; 16(Supl 1):1651-60. Disponível em: http:/ / www. scielo.br/pdf/csc/v16s1/101v16s1.pdf

24. Di Domenico M. Trocar comida por álcool? Mau negócio! Rev Boa Forma, 2009 Dez; edição 273, Saúde 109.

25. Seibel SD. Álcool. In: Seibel SD, organizador. Dependência de drogas. $2^{a}$ ed. São Paulo (SP): Atheneu; 2010. p. 119-37.

26. Lopes AD, Magalhães N. A bóia da prevenção. Rev Veja. 2009 Set; edição 2129, Saúde 86.

27. Souza JG, Lima JMB, Santos RS. Alcoolismo feminino: subsídios para prática de enfermagem. Esc Anna Nery Rev Enferm [online]. 2008 Dez [acesso 2011 Nov 29]; 12 (4):622-9. Disponível em: http:// www.scielo.br/pdf/ean/v12n4/v12n4a03.pdf

28. Brasiliano S, Hochgraf PB. A influência da comorbidade com transtornos alimentares na apresentação de mulheres dependentes de substâncias psicoativas. Rev Psiq Clín. [online]. 2006 [acesso 2011 Dez 03]; 33(3):134-44. Disponível em: http://www.scielo.br/pdf/rpc/v33n3/a03v33n3. pdf

29. Borges NJBG, Sicchieri JMF, Ribeiro RPP. Transtornos alimentares - quadro clínico. Medicina [online]. 2006 Jul-Set [acesso 2011 Dez 02]; 39(3):340-8. Disponível em: http://revista.fmrp.usp.br/2006/vol39n3/4_ transtornos_alimentares_quadro_clinico.pdf

30. Brasiliano S, Hochgraf PB. Comorbidade com transtornos alimentares. In: Seibel SD, organizador. Dependência de drogas. $2^{\mathrm{a}}$ ed. São Paulo (SP): Atheneu; 2010. p. 727-47.

31. Alzuguir FV. Álcool e gênero: uma combinação moral. Centro Lat-Am Sexualid Direit Hum [online]. 2012 Jan [acesso 2013 Mar 12]; Disponível em: http://www.clam.org.br/entrevistas/conteudo. asp?cod=9131

32. Melo CM, Oliveira DR. O uso de inibidores de apetite por mulheres: um olhar a partir da perspectiva de gênero. Ciênc Saúde Coletiva [online]. 2011 Mai [acesso 2011 Dez 01]; 16(5):2523-32. Disponível em: http://www.scielo.br/pdf/csc/v16n5/a22v16n5. pdf

33. Giacomini Filho G, Caprino MP. A propaganda de cigarro: eterno conflito entre público e privado. UNIrevista [online]. 2006 Jul [acesso 2011 Dez 01]; 3(1):1-12. Disponível em: http://www.unirevista. unisinos.br/_pdf/UNIrev_Giacomini_e_Caprino. PDF

34. Ministério da Saúde (BR). Instituto Nacional do Câncer. O controle do tabagismo no Brasil: avanços e desafios. Brasília (DF): INCA [online]. 2004 [acesso 2011 Dez 01]; Disponível em: http:/ / www.inca.gov. br/tabagismo/31maio2004/tabag_br_folheto_04. pdf

35. Granville-Garcia AF, Sobrinho JEL, Araújo JC. Ocorrência de tabagismo e fatores associados em escolares. RFO [online]. 2008 Jan-Abr [acesso 2011 Set 12]; 13(1):30-4. Disponível em: http:/ / files.bvs. br/upload/S/1413-4012/2008/v13n1/a30-34.pdf

36. Serradilha AFZ, Ruiz-Moreno L, Seiffert, OMLB. Uso de tabaco entre estudantes do ensino técnico de enfermagem. Texto Contexto Enferm [online]. 2010 Jul-Set [acesso 2011 Dez 03]; 19(3):479-87. Disponível em: http://www.scielo.br/pdf/tce/ v19n3/a09v19n3.pdf

37. Borges MTT, Barbosa RHS. As marcas de gênero no fumar feminino: uma aproximação sociológica do tabagismo em mulheres. Ciênc Saúde Coletiva [online]. 2009 [acesso 2011 Nov 13]; 14(4):1129-39. Disponível em: http://www.scielosp.org/pdf/csc/ v14n4/a14v14n4.pdf

38. Soares BM, Ilgenfritz I. Prisioneiras: vida e violência atrás das grades. Rio de Janeiro (RJ): Garamond; 2002.

39. OliveiraJF, Nascimento ER, Paiva MS. Especificidades de usuários(as) de drogas visando uma assistência baseada na heterogeneidade. Esc Anna Nery Rev Enferm [online]. 2007 Dez [acesso 2011 Dez 02]; 11 (4):694-8. Disponível em: http://www.scielo.br/ pdf/ean/v11n4/v11n4a22.pdf

40. Barcinski M. Centralidade de gênero no processo de construção da identidade de mulheres envolvidas na rede do tráfico de drogas. Ciênc Saúde Coletiva [online]. 2009 [acesso 2010 Jun 21]; 14(5):1843-53. Disponível em: http:/ / www.scielosp.org/pdf/csc/ v14n5/26.pdf

41. Baptista MC, Noto AR, Nappo AS, Carlini EA. O uso de êxtase (MDMA) na cidade de São Paulo e imediações: um estudo etnográfico. J Bras Psiquiatr. 2002 Mar-Abr; 51(2):81-9.

42. Souza MRR, Oliveira JF. Fenômeno das drogas: análise de reportagens veiculadas num jornal de Salvador. Rev Baiana Enferm. 2008 Jan-Dez; 22/23(1/3):145-56. 
43. Soares R, Rogar S. Uma droga brutal. Rev Veja. 2009 Nov; Edição 2137, Brasil 66-67.

44. Deslandes SF. Drogas e vulnerabilidade às violências. In: Minayo MCS, Souza ER. Violência sob o olhar da saúde: a infrapolítica da contemporaneidade brasileira. Rio de Janeiro (RJ): FIOCRUZ; 2003. p.243-68. 